\title{
Controversial: Early Innate Responses to Hepatitis B Virus Infection, an Explanation for Viral Persistence?
}

\author{
Ruth Broering ${ }^{1}\left(\mathbb{D} \cdot\right.$ Xufeng Luo $^{1} \cdot \mathrm{Jia}_{\mathrm{Liu}}^{2} \cdot$ Mengji Lu
}

Received: 11 February 2020 / Accepted: 3 April 2020/ Published online: 6 July 2020

(C) The Author(s) 2020

Hepatitis B virus (HBV) infection is one of the most common causes for liver related morbidity and mortality worldwide. Liver fibrosis and cirrhosis occur in the course of chronic HBV infection, with the increasing risk to develop hepatocellular carcinoma. In about $95 \%$ of adults' acute hepatitis B virus infection is self-limited, whereas in $90 \%$ of young children HBV infection leads to chronic progression. It is likely that a fully developed immune system contributes to HBV clearance (Dandri and Locarnini 2012; Bertoletti and Kennedy 2015). However, investigations of acute HBV infection in chimpanzees revealed a lack of any inducible immune genes related to viral entry and replication at early time points (Wieland et al. 2004). It has been suggested that HBV may not be recognized by the immune system and therefore has been described as stealth virus. However, the viral clearance phase is accompanied by the expression of genes related to $\mathrm{T}$ lymphocyte and interferon (IFN)-gamma responses. Assuming, that HBV-specific CD8 T cell effector functions and an appropriate CD4 $\mathrm{T}$ cell response can lead to viral clearance (Wieland and Chisari 2005). The stealth properties of HBV have recently been questioned, and it has been shown that in the early phase of infection primary human hepatocytes (PHH) sense HBV particles via toll-like receptor 2 (TLR2) (Zhang et al. 2020). This leads to the production of inflammatory cytokines including interleukin 6 (IL6) and tumour necrosis factor (TNF) which are able to suppress HBV replication in an interferon-independent

Ruth Broering

ruth.broering@uni-due.de

1 Department of Gastroenterology and Hepatology, University Hospital Essen, University of Duisburg-Essen, 45147 Essen, Germany

2 Department of Infectious Diseases, Union Hospital, Tongji Medical College, Huazhong University of Science and Technology, Wuhan 430022, China

3 Institute of Virology, University Hospital Essen, University of Duisburg-Essen, 45147 Essen, Germany manner (Hosel et al. 2009; Zhang et al. 2012). TLR2 activation has also been described for Kupffer cells/macrophages exposed to HBV particles in vitro (Cheng et al. 2017; Song et al. 2019; Zhang et al. 2020). This hepatic innate response results in cytokine and chemokine secretion that on the one hand may limit HBV replication and on the other hand orchestrates adaptive immune responses in the early phase of infection.

"Stealth" virus may be not a correct description of $\mathrm{HBV}$, as HBV infection induces relevant cellular responses in the early phase and the consequences of these events remain to be elusive. For example, IL10 expression may contribute to the establishment of intrahepatic immune tolerance. Activation of TLR2 signaling may delay, but do not prevent, HBV spread and persistent replication in hepatocytes (Zhang et al. 2020). The liver is the site of tolerance induction, and innate immune responses in TLRstimulated PHH include pro-inflammatory cytokines (IL6, IL1B, TNF) as well as anti-inflammatory cytokines (IL10) (Broering et al. 2014). Repetitive stimulation of pattern recognition receptors results in faded effector functions and an IL10-mediated anti-inflammatory microenvironment. It might be suggested here, that during 4-12 weeks incubation after HBV infection, hepatic innate immune signatures facilitate the viral spread within the liver, which is characterized by an absence of viral antigens (HBeAg or $\mathrm{HBsAg}$ ) in the blood. Interestingly, a study about acute HBV infection in a human cohort, identified a peak of IL10 serum level within the viremia phase of infection (Dunn et al. 2009), suggesting that once hepatic tolerance prevailed, HBV viremic phase starts, followed by symptomatic disease progression. Within this study, two asymptomatic patients only had very low IL10 levels and directly cleared the virus in the incubation period (Dunn et al. 2009). In murine models, Pam3Cys- and HBV-mediated hepatic TLR2 signaling has been linked with Kupffer cell expansion and KC-related IL10 production, resulting in T cell tolerance (Liu et al. 2018) and exhaustion (Li et al. 2015). Here, KCs produce IL10 upon TLR2 
activation in response to hepatitis $B$ antigens, and the elevated IL10 inhibits CD8 T cell function in HBV carrier mice. Interestingly, the presence of functional TLR2 is linked to viral persistence, whereas TLR2 deficiency results in clearance of $\mathrm{HBV}$ ( $\mathrm{Li}$ et al. 2015). Human Kupffer cells (Cheng et al. 2017) and macrophages/monocytes respond to in vitro treatment with cell culture-derived HBV and patient-derived HBsAg, with an increase in cytokine expression as well (Song et al. 2019). Thus, hepatic innate immune responses are a major determinant of the progression and outcome of $\mathrm{HBV}$ infection (Fig. 1). Can the lack of hepatic inflammation in the early phase of infection be explained by the hepatic anti-inflammatory microenvironment? Or is the low expression of relevant TLRs or rather their refractory downstream signals due to exhaustion?

The mechanisms contributing to persistence of hepatotrophic viruses like $\mathrm{HBV}$ are still elusive. It is likely, that failure of $\mathrm{HBV}$-specific CD8 $\mathrm{T}$ cell response is a major cause and is possibly mediated by the emergence of viral escape mutations, $\mathrm{T}$ cell exhaustion and development of regulatory $\mathrm{T}$ cells due to the inhibitory hepatic environment (Knolle and Thimme 2014). In addition, a shift from TH1 to TH17 CD4 $\mathrm{T}$ cell helps contribute to the loss of CD8 T cell effector functions. Furthermore, TLR2 expression in peripheral CD4 $\mathrm{T}$ cells promotes $\mathrm{TH} 17$ responses, which are associated with disease exacerbation in chronic HBV infection (Xu et al. 2017). Controversial findings have been reported in patients chronically infected with $\mathrm{HBV}(\mathrm{CHB})$. On one hand, reduced expression of TLR2 and suppressed
HBsAg-dependent responsiveness to its ligand (Pam3Cys) occur in PBMC of CHB patients (Chen et al. 2008). On the other hand, the reduced expression of TLR2 on hepatocytes, Kupffer cells and peripheral monocytes has been described only in patients with $\mathrm{HBeAg}$-positive $\mathrm{CHB}$, whereas TLR2 expression significantly increases in HBeAg-negative CHB compared with healthy controls (Visvanathan et al. 2007). The natural course of chronic hepatitis $\mathrm{B}$ consists of $\mathrm{HBeAg}$ positive and negative phases, both of which are divided into an infection phase and a hepatitis phase. HBeAg negative phases are described as immune-reactive phases with elevated levels of liver transaminases and inflammation. Liver biopsies (GSE83148) as well as peripheral blood mononuclear cells (Song et al. 2019), obtained from CHB patients, show elevated gene expression of pro-inflammatory (IL1B, IL6 and TNF) and more importantly anti-inflammatory IL10 in comparison to healthy controls. It is likely, that innate immune signaling by TLR2 is involved in the hepatitis phase of CHB and is controlled by IL10 in the infection phase. This suggestion is in accordance with an analysis of TLR2 responsiveness in PBMCs of a small cohort of HBeAg-positive CHB patients, indicating that TNF and IL6 are induced in the hepatitis phase, whereas IL10 dominates the response in immune tolerant patients (Huang et al. 2015). However, mechanistic insights into the virus strategy to utilize TLR2 signaling to persist in patients and here especially the role of IL10 remain elusive.

Innate immunity is initiated by pattern recognition receptors, which either detects extracellular pattern like

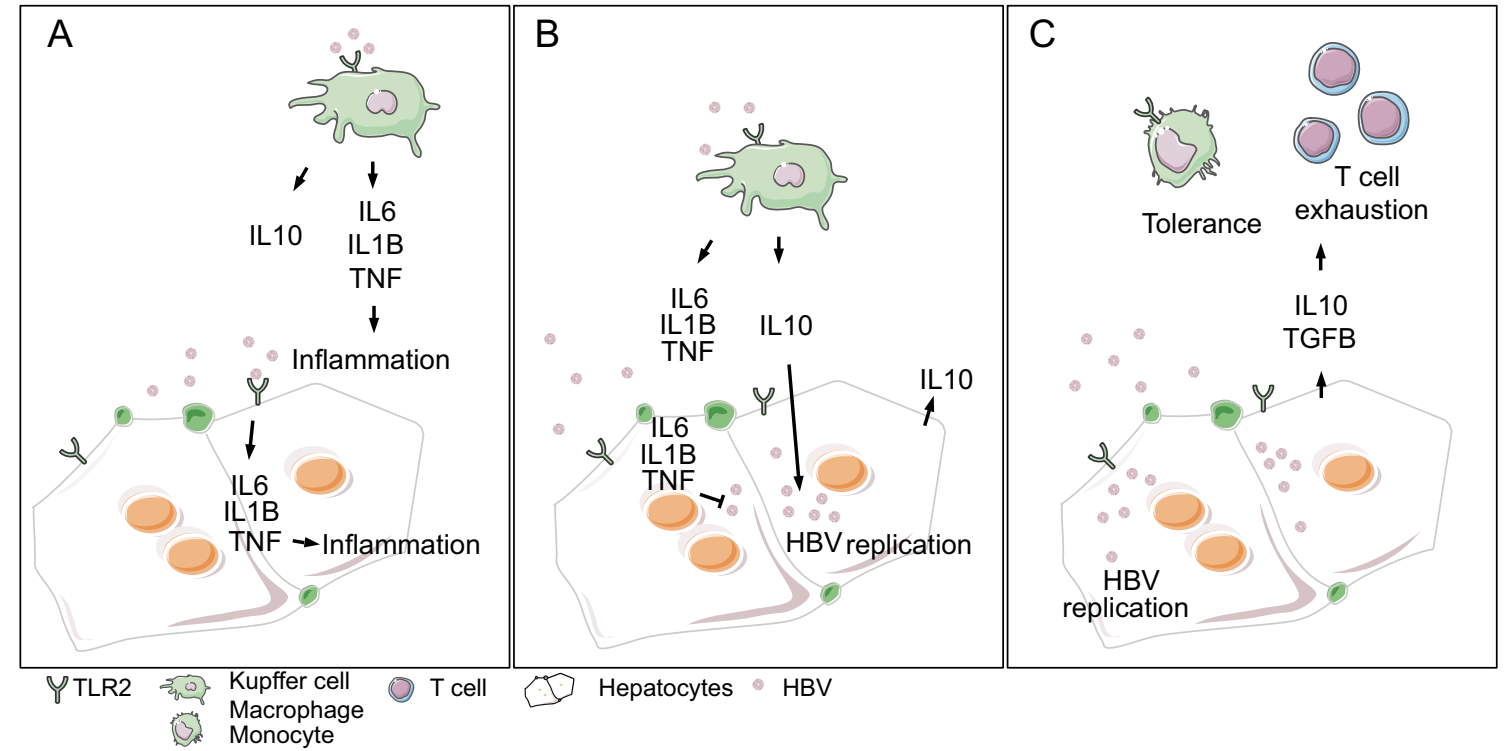

Fig. 1 Schematic overview indicating innate immune responses in the early phase of HBV infection. The anti-inflammatory microenvironment facilitates HBV replication as well as tolerance induction and $\mathrm{T}$ cell exhaustion. TLR2 signaling in the early phase of HBV infection leads to production of pro-inflammatory cytokines (A), which limits HBV replication (B). However, IL10 is induced as well, subverting the anti-HBV effect $(\mathbf{C})$. 
bacterial or fungal cell wall compounds mediating inflammatory responses or intracellular RNA or DNA molecules with foreign fingerprints that results in antiviral interferon-based processes. During HBV infection, the lack of hepatic expression of IFN and IFN-stimulated genes (ISGs) has primed the determination of stealth or invisible virus. During the early $\mathrm{HBV}$ infection, transcriptome analysis failed to show a drastic change of hepatic gene expression, especially when compared to hepatitis $\mathrm{C}$ virus infection, which is associated with a strong IFN response (Wieland et al. 2004; Wieland and Chisari 2005). This observation led to the hypothesis that HBV may evade innate immunity by passively avoiding or actively suppressing IFN induction and ISG expression. This hypothesis is supported by two additional facts. The induction of IFN production and ISG expression by immune transfer or by direct application of TLR ligands in HBV transgenic mice led to significant reduction of $\mathrm{HBV}$ replication and viral gene expression (Guidotti et al. 1996; Isogawa et al. 2005). In these studies, IFNs were found to destabilize HBV RNA at a posttranscriptional step and required the synergistic action of TNF in some instances. On the other side, HBV proteins like polymerase and $\mathrm{HBeAg}$ actively interfere with IFN signaling through the prevention of nuclear translocation of cellular transcription factors (Chen et al. 2013; Liu et al. 2015). Based on these findings, it was believed that HBV infection may be inhibited by IFNs during the early phase. However, this hypothesis may be not completely correct as shown in subsequent studies. Hydrodynamic injection is an established technique to generate mice with intrahepatic $\mathrm{HBV}$ replication. Mice injected hydrodynamically with a plasmid pAAV-HBV1.2 show long-lasting HBV replication in the liver and serve as an immune-competent mouse model for $\mathrm{HBV}$ infection (Wu et al. 2014). The induction of IFN response by polyI:C in this model had time-dependent effects: early polyI:C application together with HBV DNA results in persistent $\mathrm{HBV}$ replication at a low level while polyI:C application at later time point recruits immune cells including $\mathrm{HBV}$ specific CD8 $\mathrm{T}$ cells and leads to complete HBV clearance. Not only the time point of IFN induction but also the type of interferon determines the outcome of viral infection. Hepatic expression of IFN- $\alpha$ in the hydrodynamic $\mathrm{HBV}$ model significantly reduces $\mathrm{HBsAg}, \mathrm{HBeAg}$ and HBV DNA as well as hepatic HBcAg in the serum, whereas the expression of IFN- $\beta$ only has marginal effects on viral replication. Interestingly, the hepatic IFN- $\beta$ expression associates with IL10 expression (Zhou et al. 2017). TLR3 and RIG-I ligand polyI:C is a strong inducer of IFN- $\beta$ in the liver (Broering et al. 2014; Wu et al. 2014) which again leads to suggest that an IL10-primed hepatic environment supports HBV persistence. However, based on the current knowledge there is no evidence for endogenous TLR3 or RIG-I signaling in either acute or chronic HBV infection. Therapeutic use of interferons in $\mathrm{CHB}$ shows low response rates, and its endogenous induction via polyI: $\mathrm{C}$ has been suggested for therapeutic use. Depending on the tolerogenic microenvironment in the liver, this strategy needs to be carefully questioned.

Liver-chimeric mice, that have been developed to analyse HBV infection in vivo have revolutionized the field (Bissig et al. 2010; Lutgehetmann et al. 2012), however one major limitation of these models is the lack of a functional immune system. More recently, HBV-infection in double-humanized mice, exhibiting a human immune system and a humanized liver, has been established. Here, HBV-infected animals show human immune responses, albeit impaired liver, chronic liver inflammation and liver fibrosis. The HBV-mediated liver disease has been linked to infiltration of human macrophages with M2-like activation phenotype (Bility et al. 2014). Interestingly, the induction of inflammatory cytokines includes IL6 and IL10 (Bility et al. 2014; Dusseaux et al. 2017). A donor-matched engraftment of hepatocytes further increases the infiltration frequency of human monocytes and NK cells into the HBV-infected liver (Billerbeck et al. 2016). Thus, hepatic innate responses in the early phase of $\mathrm{HBV}$ infection likely limit viral replication and promote efficient HBV-specific immune responses, while possibly driving the IL10-dependent tolerance induction and thereby viral persistence.

Funding Open access funding provided by Projekt DEAL.

\section{Compliance with Ethical Standards}

Conflict of Interest The authors declare that they have no conflict of interest.

Animal and Human Rights Statement This article does not contain any studies with human or animal subjects performed by any of the authors.

Open Access This article is licensed under a Creative Commons Attribution 4.0 International License (https://creativecommons.org/ licenses/by/4.0/), which permits use, sharing, adaptation, distribution and reproduction in any medium or format, as long as you give appropriate credit to the original author(s) and the source, provide a link to the Creative Commons licence, and indicate if changes were made. The images or other third party material in this article are included in the article's Creative Commons licence, unless indicated otherwise in a credit line to the material. If material is not included in the article's Creative Commons licence and your intended use is not permitted by statutory regulation or exceeds the permitted use, you will need to obtain permission directly from the copyright holder. To view a copy of this licence, visit http://creativecommons.org/licenses/ by/4.0. 


\section{References}

Bertoletti A, Kennedy PT (2015) The immune tolerant phase of chronic HBV infection: new perspectives on an old concept. Cell Mol Immunol 12:258-263

Bility MT, Cheng L, Zhang Z, Luan Y, Li F, Chi L, Zhang L, Tu Z, Gao Y, Fu Y, Niu J, Wang F, Su L (2014) Hepatitis B virus infection and immunopathogenesis in a humanized mouse model: induction of human-specific liver fibrosis and M2-like macrophages. PLoS Pathog 10:e1004032

Billerbeck E, Mommersteeg MC, Shlomai A, Xiao JW, Andrus L, Bhatta A, Vercauteren K, Michailidis E, Dorner M, Krishnan A, Charlton MR, Chiriboga L, Rice CM, de Jong YP (2016) Humanized mice efficiently engrafted with fetal hepatoblasts and syngeneic immune cells develop human monocytes and NK cells. J Hepatol 65:334-343

Bissig KD, Wieland SF, Tran P, Isogawa M, Le TT, Chisari FV, Verma IM (2010) Human liver chimeric mice provide a model for hepatitis $\mathrm{B}$ and $\mathrm{C}$ virus infection and treatment. J Clin Investig 120:924-930

Broering R, Lutterbeck M, Trippler M, Kleinehr K, Poggenpohl L, Paul A, Gerken G, Schlaak JF (2014) Long-term stimulation of Toll-like receptor 3 in primary human hepatocytes leads to sensitization for antiviral responses induced by poly I: C treatment. J Viral Hepat 21:480-490

Chen Z, Cheng Y, Xu Y, Liao J, Zhang X, Hu Y, Zhang Q, Wang J, Zhang Z, Shen F, Yuan Z (2008) Expression profiles and function of Toll-like receptors 2 and 4 in peripheral blood mononuclear cells of chronic hepatitis B patients. Clin Immunol 128:400-408

Chen J, Wu M, Zhang X, Zhang W, Zhang Z, Chen L, He J, Zheng Y, Chen C, Wang F, Hu Y, Zhou X, Wang C, Xu Y, Lu M, Yuan Z (2013) Hepatitis B virus polymerase impairs interferon-alphainduced STA T activation through inhibition of importin-alpha5 and protein kinase C-delta. Hepatology 57:470-482

Cheng X, Xia Y, Serti E, Block PD, Chung M, Chayama K, Rehermann B, Liang TJ (2017) Hepatitis B virus evades innate immunity of hepatocytes but activates cytokine production by macrophages. Hepatology 66:1779-1793

Dandri M, Locarnini S (2012) New insight in the pathobiology of hepatitis B virus infection. Gut 61(Suppl 1):i6-17

Dunn C, Peppa D, Khanna P, Nebbia G, Jones M, Brendish N, Lascar RM, Brown D, Gilson RJ, Tedder RJ, Dusheiko GM, Jacobs M, Klenerman P, Maini MK (2009) Temporal analysis of early immune responses in patients with acute hepatitis B virus infection. Gastroenterology 137:1289-1300

Dusseaux M, Masse-Ranson G, Darche S, Ahodantin J, Li Y, Fiquet O, Beaumont E, Moreau P, Riviere L, Neuveut C, Soussan P, Roingeard P, Kremsdorf D, Di Santo JP, Strick-Marchand H (2017) Viral load affects the immune response to HBV in mice with humanized immune system and liver. Gastroenterology 153:1647-1661.e1649

Guidotti LG, Ishikawa T, Hobbs MV, Matzke B, Schreiber R, Chisari FV (1996) Intracellular inactivation of the hepatitis B virus by cytotoxic T lymphocytes. Immunity 4:25-36

Hosel M, Quasdorff M, Wiegmann K, Webb D, Zedler U, Broxtermann M, Tedjokusumo R, Esser K, Arzberger S, Kirschning CJ, Langenkamp A, Falk C, Buning H, Rose-John S, Protzer U (2009) Not interferon, but interleukin-6 controls early gene expression in hepatitis $B$ virus infection. Hepatology 50:1773-1782

Huang Z, Ge J, Pang J, Liu H, Chen J, Liao B, Huang X, Zuo D, Sun J, Lu M, Zhang X, Hou J (2015) Aberrant expression and dysfunction of TLR2 and its soluble form in chronic HBV infection and its regulation by antiviral therapy. Antivir Res 118:10-19

Isogawa M, Robek MD, Furuichi Y, Chisari FV (2005) Toll-like receptor signaling inhibits hepatitis $\mathrm{B}$ virus replication in vivo. J Virol 79:7269-7272

Knolle PA, Thimme R (2014) Hepatic immune regulation and its involvement in viral hepatitis infection. Gastroenterology 146:1193-1207

Li M, Sun R, Xu L, Yin W, Chen Y, Zheng X, Lian Z, Wei H, Tian Z (2015) Kupffer cells support hepatitis B virus-mediated CD8 + $\mathrm{T}$ cell exhaustion via hepatitis $\mathrm{B}$ core antigen-TLR2 interactions in mice. J Immunol 195:3100-3109

Liu S, Peng N, Xie J, Hao Q, Zhang M, Zhang Y, Xia Z, Xu G, Zhao F, Wang Q, Han T, Zhu Y (2015) Human hepatitis B virus surface and e antigens inhibit major vault protein signaling in interferon induction pathways. J Hepatol 62:1015-1023

Liu J, Yu Q, Wu W, Huang X, Broering R, Werner M, Roggendorf M, Yang D, Lu M (2018) TLR2 stimulation strengthens intrahepatic myeloid-derived cell-mediated T cell tolerance through inducing Kupffer cell expansion and IL-10 production. J Immunol 200:2341-2351

Lutgehetmann M, Mancke LV, Volz T, Helbig M, Allweiss L, Bornscheuer T, Pollok JM, Lohse AW, Petersen J, Urban S, Dandri M (2012) Humanized chimeric uPA mouse model for the study of hepatitis B and D virus interactions and preclinical drug evaluation. Hepatology 55:685-694

Song H, Tan G, Yang Y, Cui A, Li H, Li T, Wu Z, Yang M, Lv G, Chi X, Niu J, Zhu K, Crispe IN, Su L, Tu Z (2019) Hepatitis B virusinduced imbalance of inflammatory and antiviral signaling by differential phosphorylation of STAT1 in human monocytes. J Immunol 202:2266-2275

Visvanathan K, Skinner NA, Thompson AJ, Riordan SM, Sozzi V, Edwards R, Rodgers S, Kurtovic J, Chang J, Lewin S, Desmond P, Locarnini S (2007) Regulation of Toll-like receptor-2 expression in chronic hepatitis $\mathrm{B}$ by the precore protein. Hepatology 45:102-110

Wieland SF, Chisari FV (2005) Stealth and cunning: hepatitis B and hepatitis C viruses. J Virol 79:9369-9380

Wieland S, Thimme R, Purcell RH, Chisari FV (2004) Genomic analysis of the host response to hepatitis B virus infection. Proc Natl Acad Sci USA 101:6669-6674

Wu J, Huang S, Zhao X, Chen M, Lin Y, Xia Y, Sun C, Yang X, Wang J, Guo Y, Song J, Zhang E, Wang B, Zheng X, Schlaak JF, Lu M, Yang D (2014) Poly(I:C) treatment leads to interferondependent clearance of hepatitis B virus in a hydrodynamic injection mouse model. J Virol 88:10421-10431

Xu C, Lu Y, Zheng X, Feng X, Yang X, Timm J, Wu J, Wang B, Lu M, Yang D, Liu J (2017) TLR2 expression in peripheral $\mathrm{CD} 4+\mathrm{T}$ cells promotes Th17 response and is associated with disease aggravation of hepatitis B virus-related acute-on-chronic liver failure. Front Immunol 8:1609

Zhang X, Ma Z, Liu H, Liu J, Meng Z, Broering R, Yang D, Schlaak JF, Roggendorf M, Lu M (2012) Role of Toll-like receptor 2 in the immune response against hepadnaviral infection. J Hepatol 57:522-528

Zhang Z, Trippler M, Real CI, Werner M, Luo X, Schefczyk S, Kemper T, Anastasiou OE, Ladiges Y, Treckmann J, Paul A, Baba HA, Allweiss L, Dandri M, Gerken G, Wedemeyer H, Schlaak JF, Lu M, Broering R (2020) Hepatitis B virus particles activate toll-like receptor 2 signaling initial upon infection of primary human hepatocytes. Hepatology. https://doi.org/10. 1002/hep.31112

Zhou Y, Li S, Tang Z, Xu C, Huang S, Wu J, Dittmer U, Dickow J, Sutter K, Lu M, Yang D, Song J (2017) Different antiviral effects of IFNalpha and IFNbeta in an HBV mouse model. Immunobiology 222:562-570 